Кочина А.А.

Харківський національний автомобіль-дорожній університет

\title{
ОЦІНКА ВПЛИВУ НАСЕЛЕНИХ ПУНКТІВ НА ІНТЕНСИВНІСТЬ РУХУ ТРАНСПОРТНИХ ПОТОКІВ НА АВТОМОБІЛЬНИХ ДОРОГАХ ЗАГАЛЬНОГО КОРИСТУВАННЯ
}

\begin{abstract}
Робота присвячена розробці ефективних методів прогнозування інтенсивності руху транспортних потоків поблизу населених пунктів різних груп поселень. Аналіз літературних джерел показав, що розробка техніко-економічних обгрунтувань та проектів будівництва та реконструкції автомобільних доріг, формування проектів організації дорожнього руху грунтується на закономірностях формування транспортних потоків. Точність прогнозування інтенсивності транспортних потоків може значно знижуватись поблизу великих міст, це пов'язано з особливостями формування вантажних та пасажирських потоків на підходах до великих міст, величина яких зростає по мірі наближення до міста. Пошук залежності між фактичним значенням інтенсивності руху та місцем визначення ії відносно розташування ділянки до центру міста (населеного пункту) дозволяє оцінити ступень впливу міста на її величину. Результат досліджень полягає в встановленні математичного опису залежності між інтенсивністю транспортних потоків і відстані до центру міста, який надано у вигляді перетворення з використанням відстані, як основи, що приводить до збільшення зв'язку між ними. Тіснота зв'язку між інтенсивністю руху транспортних потоків і відстанню до центру міста встановлена не тільки для великих міст, а також для середніх і малих міст. Встановлений взаємозв'язок носить показниковий характер для всіх груп поселень з різною чисельністю населення та підтверджує вплив населених пунктів на інтенсивність руху транспортних потоків поблизу них. Дослідження показали, що результат оцінки впливу населених пунктів на інтенсивність руху транспортних потоків 3 достатньої точністю описується регресійними рівняннями, в яких як змінні виступають параметри, які характеризують населені пункти, а саме віддаленість від центру населеного пункту та чисельність населення. Статистична оцінка отриманих моделей свідчить про допустимість їх використання для прогнозування інтенсивності транспортних потоків поблизу населених пунктів.

Ключові слова: інтенсивність руху, транспортний потік, ступень впливу, відстань, кореляція, група поселень, чисельність населення, модель.
\end{abstract}

\section{ВСТУП}

В даний час збільшується взаємовплив та взаємозв'язок міста 3 його оточенням, який характеризується тим, що ділянки автомобільних доріг (АД) на підходах до великих міст відчувають підвищене транспортне навантаження, яке збільшується у мірі наближення до межі міста. Особливістю формування транспортних потоків на цих ділянках викликано наявністю рекреаційних зон, розміри яких залежать від величини міста. Наявність таких зон формує маятниковий рух, який пов'язаний $з$ переселенням міських жителів за місто, вид транспорту, який використовується для поїздок у місто, виключно легковий, рівень автомобілізації цієї частини населення, як правило, може удвічі перевищує середній рівень автомобілізації у регіоні. Маятниковий рух призводить до нерівномірності руху протягом доби в різних напрямках і виникнення заторів у години пік. Поряд 3 цим, АД на підходах до великих міст, як правило, є ділянками найважливіших автомагістралей нашої країни, що зв'язують найбільші транспортні вузли та забезпечують транзитні, в тому числі міжнародні, транспортні зв'язки.

Прогнозування величини інтенсивності руху (IP) транспортних потоків (ТП) на підходах до великих міст створює основу для розробки техніко-економічних обгрунтувань будівництва та реконструкції АД, формування проектів з організації дорожнього руху та прогнозування попиту на пересування, як мешканців прилеглих зон до міської території так і для мешканців міста.

\section{АНАЛІЗ ЛІТЕРАТУРНИХ ДАНИХ ТА ПОСТАНОВКА ПРОБЛЕМИ}

На величину IP ТП може впливати багато факторів, які повинні бути направлені на визначення ролі і місця міста в системі міжнародних, державних і регіональних соціально-економічних, культурно-історичних і ін. сферах. Важливим $є$ характер і зміст системи розселення населення і місць праці в зоні впливу міста - центру і його оточення, рівень автомобілізації населення і його транспортна рухомість, рівень розвитку транспортної інфраструктури та ін. Частина цих факторів визначає умовно постійну складову частку завантаження автомобільних доріг в будні дні тижня, частина 3 них - змінну частку, яка визначається нерівномірністю IP по сезонам року, дням тижня, годинам доби та напрямкам руху. Величина IP пасажирського транспорту залежить від цілі поїздки та визначає вибір виду транспорту і часу поїздки. Величина IP вантажного транспорту в значному ступені залежить від виду вантажу, що вносить суттєву невизначеність у процеси їхнього формування. 
В роботах $[1,2,3,4]$ визначення величини IP засновано на використанні факторів, які враховують характеристики населених пунктів такі, як чисельність мешканців населених пунктів та їх адміністративна значимість, яка визначає мобільність населення. При визначенні кореспонденцій між населеними пунктами враховується відстань та зона впливу кожного населеного пункту. Серед узагальнених показників використовується рівень автомобілізації, експлуатаційні показники вантажних автомобілів і автобусів та характеристика технічного стану ділянок автодоріг. Усі перераховані показники визначаються як середні, або табличні (еталоні), що суттєво знижує точність прогнозування IP при відсутності фактичних значень, отримати об'єктивну оцінку яких далеко не завжди можливо.

В підході [5] прогнозне значення IP визначається в залежності від середнього потоку на конкретній ділянці і відстані від міста на основі регресійної моделі. Максимальне зростання інтенсивності безпосередньо біля міста за моделлю складає приблизно 3 рази, хоча фактичні значення можуть бути як значно меншими, так й навпаки, значно більшими. Це обумовлене не досить високим, щодо цілей прогнозування, коефіцієнтом детермінації, який складає лише 38,2%. Пояснення недостатньої прогностичної можливості моделі полягає у наявності інших факторів, що здійснюють вплив на величину ТП в околицях міст.

У приведених методиках враховується закономірності формування величини IP ТП тільки для маятникового руху, але не враховуються закономірності формування транзитного та місцевого руху, який визначається загальними обсягами перевезень вантажів та пасажирів.

Згідно 3 [6] IP на АД загального користування суттєво залежить від відстані до центру міста. Статистичні характеристики моделі є дуже високими, що підтверджує залежність інтенсивності ТП від відстані до центру міста. Для отримання моделі використані дані величини IP лише магістральних АД загального користування, що потребує розширення на увесь спектр автомобільних доріг на національному та регіональному рівні. Це вочевидь потребуватиме збільшення кількості факторних ознак, що здійснюють вплив на величину ТП.

Отримані моделі в роботі [7] дозволили врахувати характеристики населених пунктів для різних видів транспортних засобів. 3 точку зору ступені впливу міста в залежності від його приналежності до групи поселень, цей вплив може бути різний в кожній групі, або взагалі його може не бути для невеликих поселень. Відповідно до такої характеристики доцільно дослідити залежність IP від встановлених факторів для кожної групи поселень для встановлення їх впливу на ії̈ величину.

\section{ЦІЛЬ ТА ЗАДАЧІ ДОСЛІДЖЕННЯ}

Метою дослідження $є$ формалізація математичного опису впливу характеристик населених пунктів на інтенсивність руху транспортних потоків на мережі міжнародних, національних та регіональних дорогах загального користування для різних груп поселень. Для досягнення поставленої мети вирішувались наступні завдання:

- встановити взаємозв'язок між величиною інтенсивності руху та місцем ії визначення відносно населеного пункту для визначення ступеню впливу;

- виявлення факторів, що впливають на величину інтенсивності руху для різних груп поселень;

- математична формалізація впливу параметрів, які характеризують населені пункти, на інтенсивність руху транспортних потоків на автомобільних дорогах загального користування для різних груп поселень.

\section{РЕЗУЛЬТАТИ ДОСЛІДЖЕНЬ}

Оцінити вплив міста та його характеристик можливо на основі статистичних даних інтенсивності транспортних зв'язків [8]. Одним з показників, який характеризує інтенсивність транспортних зв'язків, $€$ IP ТП. Встановити взаємозв'язок між IP ТП та, наприклад, кількістю мешканців населених пунктів, можливо за умови використання даних для різних груп міст. Необхідною умовою для встановлення взаємозв'язку між IP ТП та містом також повинні бути дані IP ТП по мережі доріг різних категорій, до яких повинні відноситись не тільки міжнародні та національні автомобільні дороги загального користування, а й регіональні дороги, які певною мірою характеризують як приміське сполучення так маятниковий рух в напрямку міста та навпаки.

Важливе значення має характеристика ділянки визначення IP, яка повинна мати точні дані про розташування місця заміру IP відносно населеного пункту, а саме відстань від межі міста або адміністративного чи історичного центру міста. У роботі [7] вдалося знайти ефективне логарифмічне перетворення з використанням відстані до центру міста як основи, що приводить до збільшення кореляційного зв'язку між фактичним значенням IP ТП та відстанню:

$$
N^{\prime}=\log _{L} N \text {, }
$$


де $L$ - відстань між центром населеного пункту та місцем визначення IP ТП на ділянці автомобільної дороги загального користування, км;

$N$ - фактичне значення IP ТП, авт./доб;

$N^{\prime}$ - перетворення IP ТП залежно від відстані $L$.

При дослідженні розглядались ділянки поблизу населених пунктів районного та обласного значення з чисельністю населення більш 7 тис. осіб. Потреба в застосуванні запропонованого підходу на прикладі міст для різних груп населених пунктів надасть можливість визначити наявність цього зв'язку не тільки для великих міст, а також для середніх та малих населених пунктів, які не відносяться до обласних центрів й можуть не утворювати вплив на IP. Фактичні значення інтенсивності, отримані за допомогою натурних обстежень, були надані Держаним агентством автомобільних доріг України. Склад транспортних потоків на автомобільних дорогах загального користування включає в себе 9 категорій ТЗ: легкові, вантажні легкі, вантажні середні, вантажні важкі, автобуси середні, автобуси важкі, тягачі, автопоїзди, мотоцикли та інші. Транспортні потоки визначались протягом доби на визначених місцях автомобільної дороги відповідної категорії. Обстеження проводились для різних категорій доріг, які мають різні характеристики. Відстані були визначені між ділянкою автомобільної дороги в місці їі фіксації (відстань від початку відповідної траси) та центру найближчого міста до цієї ділянки. Значення відстаней було отримано за допомогою сервісу [9]. У результаті було отримано 713 значень для 81 населеного пункту на території України.

На рисунку 1 представлено кореляційне залежність між IP ТП та $L$ для фактичних значень IP поблизу міст відповідно до групи поселень, яка має не яскраво виражену щільність та направленість, а також перетворених значень згідно залежності (1) на якій спостерігається збільшення щільності та направленості.

Відповідно до отриманих $N$ та розрахованих значень $N^{\prime}$ було визначено значення коефіцієнту кореляції (табл.1), який характеризує ступень впливу відстані $L$ до центру міста на величину IP ТП. Підтвердження збільшення зв'язку між величинами $N$ та $L$ після перетворення згідно залежності (1) надає можливість стверджувати о впливі міста на величину IP ТП для різних груп населених пунктів та можливості прогнозування її величини для кожної групи окремо, враховуючи що цей вплив може мати різний ступень.

Таблиця 1 - Оцінка ступеню впливу відстані до міста для різних груп поселень на IP ТП

\begin{tabular}{|c|c|c|c|c|}
\hline \multirow[b]{2}{*}{ Групи поселень } & \multirow{2}{*}{$\begin{array}{l}\text { Чисельність } \\
\text { населення, } \\
\text { тис. осіб }\end{array}$} & \multirow{2}{*}{$\begin{array}{l}\text { Кількість } \\
\text { спостережень, } \\
\text { од. }\end{array}$} & \multicolumn{2}{|c|}{ Лінійний коефіцієнт кореляції } \\
\hline & & & $\begin{array}{l}\text { Відстань } L, \text { км та } \\
\text { фактична } N \text {, авт./доб }\end{array}$ & $\begin{array}{l}\text { Відстань } L, \text { км та } \\
\text { перетворена } N^{\prime}\end{array}$ \\
\hline $\begin{array}{l}\text { Найзначніші } \\
\text { (крупніші) }\end{array}$ & Понад 1000 & 89 & $-0,41$ & $-0,767$ \\
\hline Значніші (крупні) & Понад 500 до 1000 & 111 & $-0,47$ & $-0,684$ \\
\hline Великі & Понад 250 до 500 & 182 & $-0,41$ & $-0,683$ \\
\hline Середні & $\begin{array}{l}\text { Понад } 100 \text { до } 250 \\
\text { Понад } 50 \text { до } 100\end{array}$ & 133 & $-0,41$ & $-0,69$ \\
\hline Малі & $\begin{array}{l}\text { Понад } 20 \text { до } 50 \\
\text { Понад } 10 \text { до } 20 \\
\text { До } 10\end{array}$ & 198 & $-0,24$ & 0,607 \\
\hline
\end{tabular}

Можливо стверджують, що величина IP ТП на ділянках автомобільних доріг поблизу міст визначаються численними факторами і залежностями, як внутрішнього, так і зовнішнього характеру.

При визначенні факторів, які впливають на IP ТП було обрано параметри, які можливо поділити на дві групи: перша - характеризує дорожні умови, в яких здійснюється рух ТП; друга характеристики міст (населених пунктів), які знаходяться поблизу. До першої групи можливо віднести:

- кількість смуг руху $n$, од.;

- швидкість руху на ділянці дороги $V$, км/год.;

- середня інтенсивність руху $N_{c p}$, авт./доб.

До другої групи віднесено:

- чисельність населення $P$, осіб; 
- віддаленість від населеного пункту $\frac{1}{L}$, км.
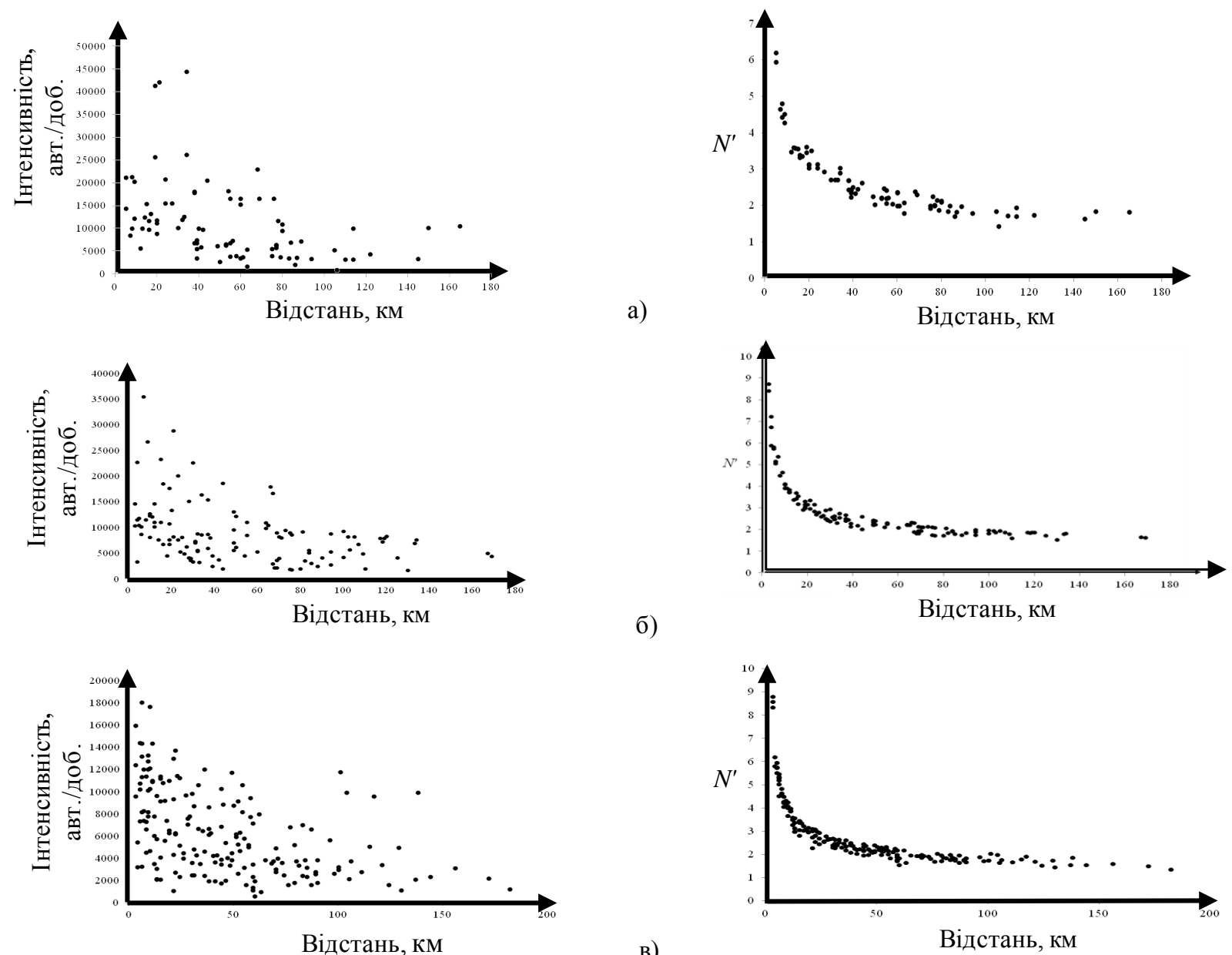

б)

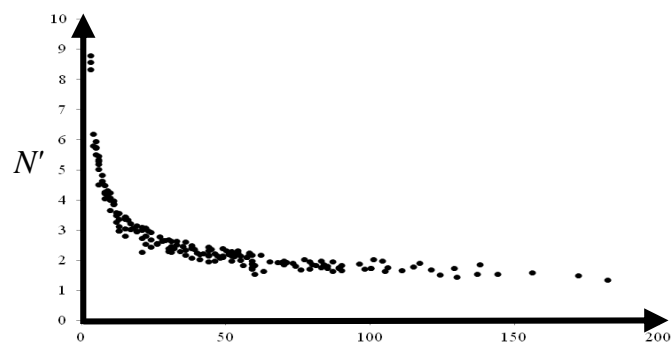

в)

Відстань, км
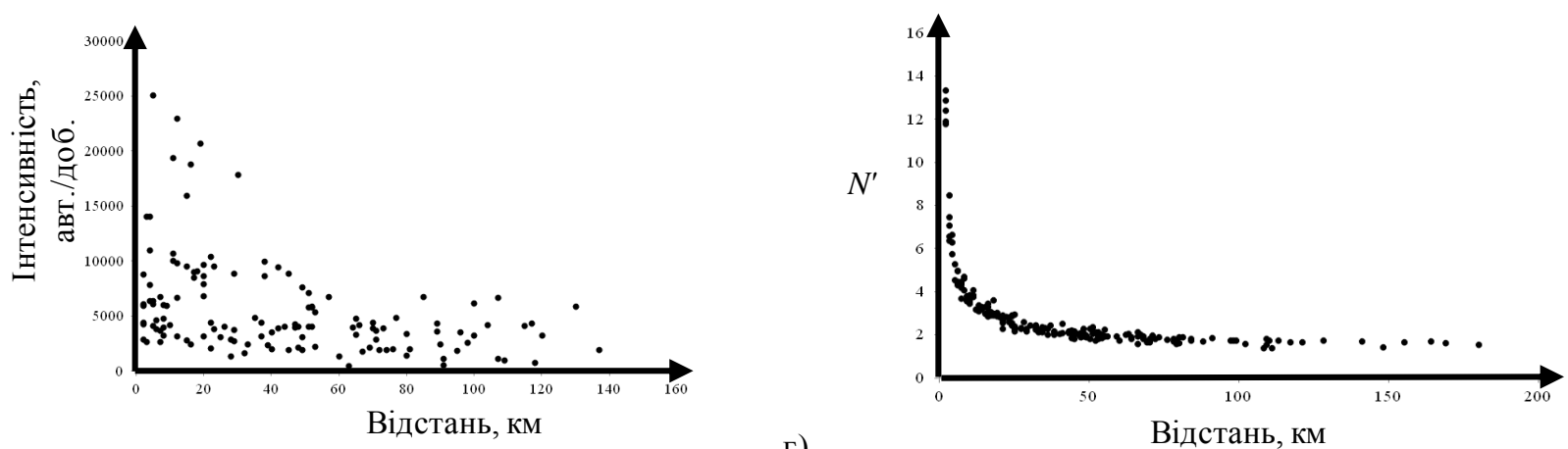

г)

Відстань, км

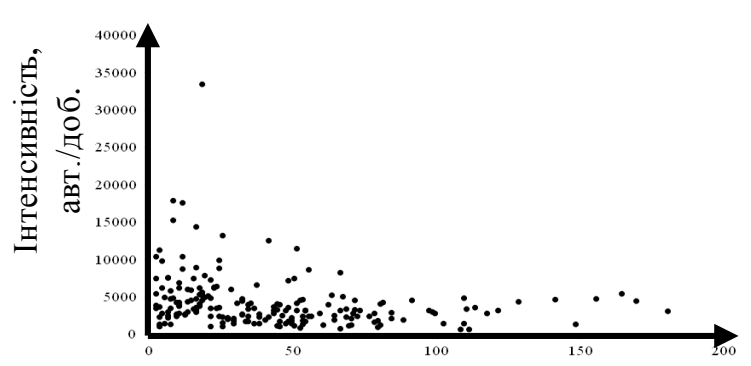

Відстань, км

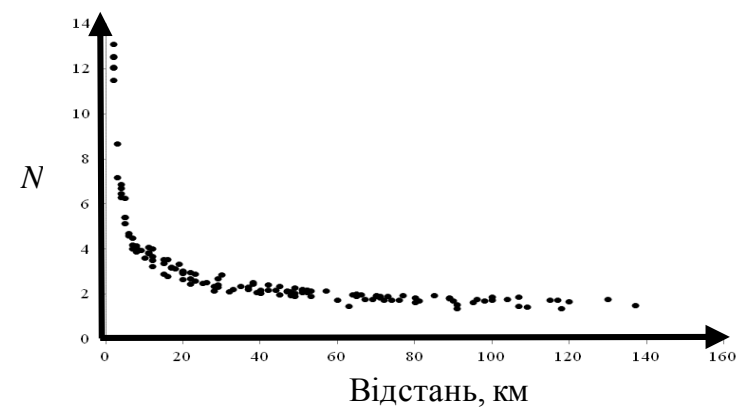

д)

Рисунок 1 - Розподіл інтенсивності руху в залежності від відстані до центру населеного пункту різних груп поселень: а - найзначніші (крупніші) міста; б - значніші (крупні) міста; в - великі міста; г - середні міста; д- малі міста 
В результаті розрахунків параметри $N_{c p}, V$ та $n$ згідно регресійного аналізу [10] були визначені, як фактори які не здійснюють вагомого впливу на IP ТП. Відповідно до результатів розрахунків були отримання моделі для усіх груп поселень:

- Крупніші міста

$$
\begin{array}{r}
N^{\prime}=\log _{L} N=1,7108+0,00004 \cdot P+22,969 \cdot \frac{1}{L} ; \\
- \text { Крупні міста } \\
\begin{array}{r}
N^{\prime}=\log _{L} N=1,535+0,00037 \cdot P+20,645 \cdot \frac{1}{L} ; \\
- \text { Великі міста }
\end{array} \\
N^{\prime}=\log _{L} N=1,644+0,00023 \cdot P+20,592 \cdot \frac{1}{L} ; \\
- \text { Середні міста } \\
N^{\prime}=\log _{L} N=1,624+0,00018 \cdot P+20,768 \cdot \frac{1}{L} ; \\
- \text { Малі міста } \\
N^{\prime}=\log _{L} N=1,462+0,00288 \cdot P+20,043 \cdot \frac{1}{L} .
\end{array}
$$

Після розробки регресійних моделей (2) - (6) була проведена статистична оцінка моделей. Результати розрахунків наведені в таблиці2. Результати досліджень показали, що при оцінки впливу міста на IP ТП з усіх досліджуваних факторів значимими виявилися тільки віддаленість від міста та

\begin{tabular}{|c|c|c|c|c|c|}
\hline \multirow{3}{*}{ Показники } & \multicolumn{5}{|l|}{ Значення } \\
\hline & \multicolumn{5}{|c|}{ Групи поселень } \\
\hline & $\begin{array}{l}\text { Найзначніші } \\
\text { (крупніші) }\end{array}$ & $\begin{array}{l}\text { Значніші } \\
\text { (крупні) }\end{array}$ & Великі & Середні & Малі \\
\hline Коефіцієнт множинної кореляції & 0,966 & 0,984 & 0,984 & 0,992 & 0,983 \\
\hline Коефіцієнт детермінації & 0,935 & 0,969 & 0,968 & 0,983 & 0,967 \\
\hline Середня похибка апроксимації & 0.234 & 0.241 & 0.233 & 0.309 & 0,356 \\
\hline Критерій Фішера & 618,17 & 1686,42 & 2751,63 & 3860,72 & 2841,63 \\
\hline
\end{tabular}
чисельність населення, які характеризують населений пункт. Про це свідчить розрахункове значення критерію Стьюдента, яке більше табличного значення. Тіснота зв'язку між залежною змінною i факторами, що впливають на іï рівень, визначалася коефіцієнтом множинної кореляції. Його значення свідчить про високий ступінь тісноти зв'язку між значеннями перетвореної IP ТП і відібраними факторами. Оцінка адекватності розробленої моделі проводилась за показником середньої помилки апроксимації. Іїї значення відповідає допустимим межам

Таблиця 2 - Результати оцінки моделей впливу населених пунктів різних груп поселень на інтенсивність руху транспортних потоків

Результати розрахунків вказують на значно кращій результат між параметрами моделей, що дозволяє зробити висновок о можливості застосування запропонованого підходу для прогнозування IP.

\section{ОБГОВОРЕННЯ РЕЗУЛЬТАТІВ ДОСЛІДЖЕННЯ}

Визначені фактори згідно експериментальних досліджень, які впливають на величину IP ТП свідчать про доцільність використання характеристик населених пунктів для прогнозування величини IP ТП. Застосування запропонованої методики доцільно розглядати для міст різної категорії, які мають різну чисельність населення та підпорядкованість (обласний та районний центр).

Відповідно до отриманих моделей 2 - 6 для моделювання IP T3 необхідно виконати математичні перетворення для отримання значення величини транспортного потоку. Як було зазначено згідно теоретичних досліджень для отримання величини IP перехід до змодельованого значення $N$ можливо за допомогою математичного виразу цієї величини згідно отриманої регресійної моделі враховуючи параметри моделі, які виявились значимими згідно регресійного аналізу. 
Відповідно до цього для отримання змодельованої величина $N$ для різних груп населених пунктів буде мати наступний вигляд:

$$
\begin{aligned}
& \text { - Крупніші міста } \\
& N=e^{\left(1,7108+0,00004 P+22,969 \frac{1}{L}\right) \operatorname{Ln} L} \\
& \text { - Крупні міста } \\
& N=e^{\left(1,535+0,00037 P+20,645 \frac{1}{L}\right) L n L} \\
& \text { - Великі міста } \\
& N=e^{\left(1,644+0,00023 P+20,592 \cdot \frac{1}{L}\right) L n L} \\
& \text { - Середні міста } \\
& N=e^{\left(1,624+0,00018 P+20,768 \frac{1}{L}\right) L n L} . \\
& \text { - Малі міста } \\
& N=e^{\left(1,462+0,00288 P+20,043 \frac{1}{L}\right) L n L} .
\end{aligned}
$$

В таблиці 3 представлені максимальні та середні значення розрахункових даних для різних груп поселень.

Таблиця 3 - Результати моделювання інтенсивності руху

\begin{tabular}{|l|l|l|l|}
\hline \multirow{2}{*}{ Групи поселень } & \multicolumn{3}{|c|}{ Величина $N$ по моделі, авт./доб. } \\
\cline { 2 - 4 } & Максимальна & Середня & Мінімальна \\
\hline Найзначніші (крупніші) & 23697 & 10828 & 6589 \\
\hline Значніші (крупні) & 20957 & 9035 & 4165 \\
\hline Великі & 14783 & 6245 & 4724 \\
\hline Середні & 9182 & 5617 & 4924 \\
\hline Малі & 8151 & 4293 & 2070 \\
\hline
\end{tabular}

Максимальне відхилення на окремих ділянках перевищує 20 \%, що пояснюється відповідності фактичним даних о завантажених ділянках на яких пропускна здатність менш ніж потік транспортних засобів. Такі ситуації не можуть бути враховані при моделюванні з використанням тільки чисельності населення. Для цього необхідно розширення параметрів, які будуть враховувати об'єкти тяжіння для транспортного потоку на рівні місцевих органів управління при наявності більш детальної інформації.

Не зважаючи на значні відхилення на окремих ділянках загальна тенденція зросту IP по мірі наближення до міста була отримана для різних категорій доріг на яких розташовані міста 3 різною чисельністю населення.

\section{ВИСНОВКИ}

В роботі було виявлено, що на інтенсивність руху транспортного потоку на автомобільних дорогах загального користування суттєво впливає наявність населених пунктів та їх характеристики, але характер цього зв'язку $є$ дуже випадковим та не може бути описаний без ефективного перетворення змінних. Дослідження показало, що вплив населених пунктів на інтенсивність руху найбільш ефективно описує логарифмічне перетворення з використанням відстані від центру міста за основою та 3 достатньою точністю описується регресійним рівнянням, в якому як змінні виступають характеристики населених пунктів за віддаленістю та чисельністю населення. Також доцільно розглядати результат регресійного аналізу для кожної групи поселень окремо для врахування обмежень по чисельності населення, що дозволяє отримати більш точний результат. Статистична оцінка отриманих моделей свідчить про допустимість їх використання для прогнозування величини транспортних потоків при розробки техніко-економічного обгрунтування та проектів будівництва та реконструкції автомобільних доріг, формування проектів організації дорожнього руху.

\section{ПЕРЕЛІК ДЖЕРЕЛ ПОСИЛАННЯ}

1.Методичні рекомендації з визначення існуючої та прогнозування перспективної інтенсивності руху: МР А.2.1-218-02070915-729. Київ, 2008. - 25 с. 
2.Методика економічних вишукувань для проектування автомобільних доріг: М 218-05416892409. Київ, 2004. - 34 с.

3.Методические рекомендации по проектированию автомобильных дорог на подходах к крупным городам: ОДМ 2010. Москва 2010. - 263 с.

4.Dmitriy Dzhuruk, Anton Zedgenizov \ Forecasting of traffic intensity on suburban routes \ Thirteenth International Conference on Organization and Traffic Safety Management in Large Cities (SPbOTSIC 2018) Transportation Research Procedia 36 (2018) 135-140

5.Розроблення методики прогнозування автотранспортних потоків на автомобільних дорогах загального користування державного значення та розроблення вимог до даних, що використовуються при прогнозуванні, порядку їх збирання і обробки, вимоги до вихідних даних прогнозів для занесення до Єдиної інформаційної геобази даних автомобільних доріг України: Звіт про ДКР (проміжний) / Державне агентство автомобільних доріг України, ХНАДУ; № держ. реєстрації 0114U004631. Харків, 2015. - 99 с.

6.Горбачов П.Ф., Кочина А.А. Вплив поїздок у приміському сполученні на інтенсивність руху на автомобільних дорогах загального/ Вестник Харьковского национального автомобильнодорожного университета. Сборник научных трудов. -Х.: Изд-во ХНАДУ, 2016 - Вып. 72. - С. 83-87.

7.Горбачов П.Ф. Оцінка впливу населених пунктів на інтенсивність руху транспортних потоків у приміському сполученні. /П.Ф.Горбачов, А.А. Кочина // Автомобільний транспорт. - Харків. 2017. - № 40. - C. 48-55.

8..Введение в математическое моделирование транспортных потоков: учеб. пособие / Гасников А.В., Кленов С.Л., Нурминский Е.А., Холодов Я.А., Шамрай Н.Б.; приложения: Бланк М.Л., Гасникова Е.В., Замятин А.А. и Малышев В.А., Колесников А.В., Райгородский А.М //; под ред. А.В. Гасникова. - М.: МФТИ, 2010. - 362 с.

9.Картографічні дані [Електронний ресурс]. - Режим доступу https://www.google.com.ua/maps/.

10.Галушко В.Г. Вероятностно-статистические методы на автотранспорте. - Изд. объединение «Вища школа», 1976. - 232 с.

\section{REFERENCES}

1.Metodychni rekomendatsiyi $\mathrm{z}$ vyznachennya isnuyuchoyi ta prohnozuvannya perspektivnoyi intensivnosti rukhu. (2008) MR A.2.1-218-02070915-729, 25.

2.Metodyka ekonomichnykh vyshukuvan' dlya proektuvannya avtomobil'nykh dorih (2004): M 21805416892-409, 34.

3.Methodical recommendations for designing highways in approaches to large cities. (2010), 263.

4.Dmitriy Dzhuruk, Anton Zedgenizov \Forecasting of traffic intensity on suburban routes $\backslash$ Thirteenth International Conference on Organization and Traffic Safety Management in Large Cities (SPbOTSIC 2018) Transportation Research Procedia 36 (2018) 135-140.

5.Rozroblennya metodyky prohnozuvannya avtotransportnykh potokiv na avtomobil'nykh dorohakh zahal'noho korystuvannya derzhavnoho znachennya ta rozroblennya vymoh do danykh, shcho vykorystovuyut'sya pry prohnozuvanni, poryadku yikh zbyrannya i obrobky, vymohy do vykhidnykh danykh prohnoziv dlya zanesennya do Yedynoyi informatsiynoyi heobazy danykh avtomobil'nykh dorih Ukrayiny: Zvit pro DKR (promizhnyy) / Derzhavne ahent·stvo avtomobil'nykh dorih Ukrayiny. (2015) KHNADU, № derzh. reyestratsiyi 0114U004631, 99.

6.Gorbachov P.F., Kochina A.A. (2016) Influence of commuting trips on traffic intensity on public highways. HNADU, 72, 83-87.

7.Gorbachov P.F., Kochina A.A. (2017) Otsinka vplyvu naselenykh punktiv na intensyvnist' rukhu transportnykh potokiv u prymis'komu spoluchenni. Avtomobil'nyy transport № 40, 48-55.

8.Gasnikov A.V., Klenov S.L., Nurminskiy Ye.A., Kholodov YA.A., Shamray N.B.; prilozheniya: Blank M.L., Gasnikova Ye.V., Zamyatin A.A. i Malyshev V.A., Kolesnikov A.V., Raygorodskiy A.M. (2010) Vvedeniye $\mathrm{v}$ matematicheskoye modelirovaniye transportnykh potokov: ucheb. posobiye. pod red. A.V. Gasnikova. MFTI, 362.

9. Kartohrafichni dani [Elektronnyy resurs]. - Rezhym dostupu https://www.google.com.ua/maps/.

10. Galushko V.G. (1976) Veroyatnostno-statisticheskiye metody na avtotransporte. Izd. Vishcha shkola, 232. 


\section{A. Kochina. Assessment of the influence of settlements on the intensity of traffic flows on public roads of public use}

The work is devoted to the development of effective methods for forecasting the traffic intensity of transport flows near the settlements of different groups of settlements. The analysis of literature sources showed that the development of feasibility studies and projects for the construction and reconstruction of highways, the formation of projects for the organization of road traffic is based on the laws of formation of traffic flows. The accuracy of forecasting the intensity of traffic flows can be significantly reduced near large cities, this is due to the peculiarities of the formation of freight and passenger flows on the approaches to large cities, the value of which increases as you approach the city. Finding the relationship between the actual value of traffic intensity and the place of its determination in relation to the location of the site to the city center (settlement) allows you to assess the degree of influence of the city on its value. The result of the research is to establish a mathematical description of the relationship between the traffic intensity of transport flows and the distance to the city center, which is provided in the form of a transformation using distance as a basis, which increases the relationship between them. The closeness of the connection between the traffic intensity of transport flows and the distance to the city center is established not only for large cities, but also for medium and small cities. The established relationship is indicative of all groups of settlements with different populations and confirms the impact of settlements on the intensity of traffic near them. Studies have shown that the result of assessing the impact of settlements on the intensity of traffic flows is described with sufficient accuracy by regression equations, in which the variables are parameters that characterize settlements, namely the distance from the center of the settlement and population. Statistical evaluation of the obtained models indicates the admissibility of their use to predict the intensity of traffic flows near settlements.

Keywords: traffic intensity, traffic flow, degree of influence, distance, correlation, group of settlements, population, model.

КОЧИНА Анастасія Анатолї̈вна, кандидат технічних наук, старший викладач кафедри транспортних системи і логістики, Харківський національний автомобіль-дорожній університет еmail: kochina.tsl@gmail.com. https://orcid.org/0000-0001-8377-4770

Anastasia KOCHINA, PhD in Engeneering, senior lecturer of Department Transport Systems and Logistics, Kharkiv National Automobile and Highway University e-mail: kochina.ts1@gmail.com. https://orcid.org/0000-0001-8377-4770

DOI 10.36910/automash.v1i16.510 